\title{
Synergistic effect of non starch polysaccharide enzymes, synbiotics and phytase on performance, nutrient utilization and gut health in broilers fed with sub-optimal energy diets
}

\author{
J. Narasimha, D. Nagalakshmi, Y. Ramana Reddy and S. T. Viroji Rao \\ Department of Animal Nutrition, College of Veterinary Science, Sri Venkateswara Veterinary University, \\ Rajendranagar, Hyderabad, Andhra Pradesh - 500030, India \\ Corresponding author: Narasimha J atoth, email: simha_vet@yahoo.com,fireflames.harsha579@gmail.com \\ Received: 08-04-2013, Revised: 04-06-2013, Accepted: 05-06-2013, Published online: 14-08-2013
}

doi: 10.14202/vetworld.2013.754-760 How to cite this article: Narasimha J, Nagalakshmi D, Reddy YR and Rao STV (2013) Synergistic effect of non starch polysaccharide enzymes, synbiotics and phytase on performance, nutrient utilization and gut health in broilers fed with sub-optimal energy diets, Veterinary World 6(10): 754-760.

\begin{abstract}
Aim: In view of the ban on antibiotic growth promoters (AGPs), an attempt was made to explore the possibility of harnessing synergistic effect of non starch polysaccharide (NSP) enzymes, synbiotics and phytase on performance, nutrient retention, gut health and histology of broilers fed with corn-soybean meal based low calorie diets.

Materials and Methods: A total of 150 a day-old broiler chicks were weighed, wing banded and randomly distributed into five experimental groups, six replicates per group and five birds per replicate and raised in electrically heated battery brooders. Evaluated the synergistic effect of the NSP enzymes, synbiotics and phytase alone or in combination, supplemented to cornsoybean meal based broiler diet, low in energy concentration (Basal diet (BD)) (-225 kcal lower metabolizable energy than standard diet (SD), on performance, nutrient retention, carcass traits, gut conditions and cost per kg live weight gain.

Results: The body weight gain in broiler chicks fed with BD supplemented with NSP enzymes, synbiotics and phytase was significantly $(\mathrm{P}<0.01)$ higher. Supplementation of NSP enzymes, synbiotics and phytase alone or in combination had significant effect on feed intake. Synergistic effect of NSP enzyme, synbiotics and phytase was observed on overall feed conversion ratio (1.86), which improved $(\mathrm{P}<0.05)$ in comparison to $\mathrm{BD}(2.06)$ and $\mathrm{SD}(2.02)$, respectively. The supplementation of NSP enzymes, synbiotics and phytase to BD improved $(\mathrm{P}<0.05)$ utilization of organic matter $(\mathrm{OM})$, crude protein (CP), nitrogen free extract (NFE), gross energy (GE), phosphorus and the tibia ash compared to BD, whereas no effect on retention of DM and CF was observed. Intestinal viscosity and $E$. coli count significantly $(\mathrm{P}<0.01)$ reduced with addition of NSP enzymes, synbiotics plus phytase or combination of all. The supplementation of NSP enzymes, synbiotics plus phytase had no effect on intestinal histology. The cost of feeding was lower $(\mathrm{P}<0.01)$ in BD. Addition of these feed additives to BD did not increase the feeding cost and was comparable to unsupplemented ones and lower $(\mathrm{P}<0.01)$ than SD. Similarly, the feed cost per kg live weight gain during various phases of broiler production was reduced $(\mathrm{P}<0.01)$ due to supplementation of all the feed additives compared to SD and BD.
\end{abstract}

Conclusions: It can be concluded from the above experiment that supplementing sub-optimal energy diets with NSP enzymes along with synbiotics and phytase improved body weight gain, FCR, nutrient retention, tibia ash and reduced the cost of production considerably.

Keywords: gut health, histology, live weight gain, NSPenzymes, nutrient retention, synbiotics, phytase,

\section{I ntroduction}

The productivity of broilers has improved significantly, through genetic improvements. Increased rearing density has concentrated and increased disease challenges making birds more susceptible to various pathogens especially enteropathic microbes such as Escherichia coli, Salmonella spp., Clostridium perfringens and Campyobacter spp. This increased susceptibility has resulted in the use of antimicrobial growth promoters which are primarily used to enhance gut health and control sub-clinical challenges. With increasing public health concerns about bacterial resistance to antibiotics, the use of antibiotics in therapeutic or sub-therapeutic doses in poultry feed has been severely limited or eliminated in many countries.

Copyright: The authors. This article is an open access article licensed under the terms of the Creative Commons Attribution License (http://creativecommons.org/licenses/by/2.0) which permits unrestricted use, distribution and reproduction in any medium, provided the work is properly cited.
In view of the above circumstances, there has long been interest in finding alternatives to antibiotics for poultry production. Resident microbes in the birds' digestive tract have a profound effect on some of the physiological processes of their host. It is important to understand the dynamics of the intestinal microbial ecology of the chicken to find alternatives to antibiotics. Under normal circumstances there is a delicate balance of beneficial and pathogenic bacteria in the gastrointestinal tract (GIT). This is influenced by symbiotic and competitive interactions and relationships. The microbial communities will not only protect the GIT but also enhance productivity in the host. NSP enzymes degrade NSP and by this improve gut motility and nutrient (mainly energy) availability [1]. Prebiotics are non-digestible substances, mainly oligo-and polysaccharides, lowering $\mathrm{pH}$ in the gut and by this inhibit colonization of pathogenic microorganisms, stimulate immunity and neutrale toxins. Probiotics act by competitive exclusion, lower gut $\mathrm{pH}$, produce bacteriocins, lysozyme and 
Table-1. Details of experimental diets

\begin{tabular}{ll}
\hline Diet no. & Diet \\
\hline 1 & Standard diet (SD) \\
2 & Basal diet (BD) \\
3 & BD + NSP enzymes \\
4 & BD + Synbiotics + Phytase \\
5 & BD + NSP enzymes+synbiotics + Phytase \\
\hline
\end{tabular}

1. Trace mineral provided per kg diet: Manganese $120 \mathrm{mg}$; Zinc $80 \mathrm{mg}$; Iron 25mg; Copper $10 \mathrm{mg}$; Iodine $1 \mathrm{mg}$ and Selenium $0.1 \mathrm{mg}$.

2. Vitamin premix provided per $\mathrm{kg}$ diet: Vitamin $\mathrm{A}$ 20000IU; Vitamin D3 3000IU; Vitamin E 10mg; Vitamin K 2mg; Riboflavin 25mg; VitaminB1 1mg; Vitamin B6 2mg; Vitamin B12 40mcg and Niacin 15mg.
Table-2. I ngredient composition of Basal diet (BD)

\begin{tabular}{llll}
\hline Ingredient (g/kg) & prestarter & starter & finisher \\
\hline Maize & 522.8 & 597.2 & 657.5 \\
Soybean meal & 380.2 & 342.6 & 305.0 \\
De oiled rice bran & 59.2 & 23.7 & 0.00 \\
Oil (vegetable) & 0.0 & 0.0 & 3.1 \\
Salt & 4.5 & 4.5 & 4.5 \\
DL-methionine & 2.2 & 2.1 & 1.8 \\
Di-Calcium phosphate & 18.3 & 17.7 & 16.5 \\
Shell grit & 7.7 & 7.0 & 6.8 \\
Trace mineral mixture & 1.2 & 1.2 & 1.2 \\
Vitamin premix & 0.40 & 0.40 & 0.40 \\
Choline Chloride (50\%) & 0.6 & 0.60 & 0.60 \\
Toxin Binder & 2.0 & 2.0 & 2.0 \\
Antibiotic & 0.5 & 0.50 & 0.50 \\
Coccidiostat & 0.5 & 0.50 & 0.50 \\
Total & 1000 & 1000 & \\
Nutrient Composition (calculated) & & \\
ME (kcal/kg) & 2725.0 & 2825.0 & 2925.0 \\
Protein (\%) & 22.5 & 21.00 & 19.50 \\
Calcium (\%) & 0.90 & 0.85 & 0.80 \\
Available phosphorus (\%) & 0.45 & 0.43 & 0.40 \\
Lysine (\%) & 1.23 & 1.13 & 1.03 \\
Methionine (\%) & 0.55 & 0.52 & 0.48 \\
Crude fibre (\%) & 4.37 & 3.82 & 3.39 \\
\hline
\end{tabular}

Table-3. Ingredient composition of standard diets

\begin{tabular}{llll}
\hline Ingredient (g/kg) & pre-starter & starter & finisher \\
\hline Maize & 542.0 & 572.8 & 603.9 \\
Soybean meal & 393.0 & 353.8 & 314.8 \\
Oil (veg) & 27.0 & 36.8 & 46.5 \\
Salt & 4.5 & 4.5 & 4.5 \\
DL-methionine & 2.2 & 2.1 & 1.9 \\
Di-Calcium Phosphate & 19.0 & 18.1 & 16.5 \\
Shell grit & 7.1 & 6.7 & 6.70 \\
Trace mineral mixture & 1.2 & 1.2 & 1.2 \\
Vitamin premix & 0.40 & 0.40 & 0.40 \\
Choline Chloride, 50\% & 0.6 & 0.60 & 0.60 \\
Toxin Binder & 2 & 2.0 & 2.0 \\
Antibiotic & 0.5 & 0.50 & 0.50 \\
Coccidiostat & 0.5 & 0.50 & 0.50 \\
Total & 1000 & 1000 & 1000 \\
Nutrient Composition (Calculated) & & \\
ME(kcal/kg) & 2950.0 & 3050.0 & 3150.0 \\
Protein (\%) & 22.5 & 21.0 & 19.50 \\
Calcium (\%) & 0.90 & 0.85 & 0.800 \\
Available phosphorus (\%) & 0.45 & 0.43 & 0.400 \\
Lysine (\%) & 1.24 & 1.14 & 1.04 \\
Methionine (\%) & 0.55 & 0.52 & 0.48 \\
Crude fibre (\%) & 3.69 & 3.52 & 3.34 \\
\hline
\end{tabular}

1. Trace mineral provided per kg diet: Manganese $120 \mathrm{mg}$ : Zinc 80mg; Iron 25mg; Copper 10mg; Iodine $1 \mathrm{mg}$ and Selenium $0.1 \mathrm{mg}$.

2. Vitamin premix provided per $\mathrm{kg}$ diet: Vitamin $A$ 20000IU; Vitamin D3 3000IU; Vitamin E 10mg; Vitamin K 2mg; Riboflavin 25mg; VitaminB1 1mg; Vitamin B6 2mg; Vitamin B12 40mcg and Niacin 15mg. peroxides, and stimulate the immune system. The combined application of prebiotics and probiotics is called synbiotics [2]. Feed additives if incorporated in poultry feeds, can create favourable conditions in the intestine for the efficient digestion of feed [3, 4]. Many feed additives viz., NSP enzymes, prebiotics, probiotics, acidifier more or less help in maintaining gut directly or indirectly. In most of the experiments these additives have been used singly.If two or more such additives are used in combination, possibly their effects may complement and may have synergistic effect.

Keeping these objectives in mind the present study was conducted to exploit the synergistic effect of NSP enzymes, prebiotics, probiotics (synbiotics) and phytase, on performance, nutrient retention, gut health and histology.

\section{Materials and Methods}

Ethical approval: This research work was carried out after approval of Institutional Animal Ethics Committee. Experimental design and sample collection: One hundred and fifty (150) day-old Cobb commercial broiler chicks were weighed, wing banded and randomly distributed into five experimental groups, six replicates per group and five birds per replicate. The NSP enzymes combination (xylanase $7500 \mathrm{IU} / \mathrm{kg}$, cellulase $100 \mathrm{IU} / \mathrm{kg}$ and $\beta$ - D- glucanase $100 \mathrm{IU} / \mathrm{kg}$ ), prebiotic (MOS, $0.5 \mathrm{~g} / \mathrm{kg}$ ), probiotic (Saccharomyces boullardii, $10^{8} \mathrm{CFU} / \mathrm{kg}$ ) and phytase (675 IU/kg) was tested at sub-optimal energy concentration (225 $\mathrm{kcal} / \mathrm{kg}$ less ME than standard diet) [5]. The details of experimental diets are given in Table 1, 2 and 3. All replicate groups of chicks were offered the respective diets ad libitum for a period of 42 days. Weekly body weights and feed intake were recorded. At the end of experiment, a metabolic trial of 4 day duration was conducted to determine the nutrient utilization and balance of nutrients. The samples of each feed, feed 
Table-4. Nutrient composition (\% dry matter basis) of broiler finisher standard and basal diets (analyzed)

\begin{tabular}{|c|c|c|c|c|c|c|c|c|c|}
\hline Diet & DM & OM & $\mathbf{C P}$ & EE & CF & NFE & Total ash & GE (kcal/g) & TP \\
\hline Standard diet (SD) & 92.15 & 93.93 & 19.85 & 6.22 & 3.34 & 64.52 & 6.07 & 3.85 & 0.46 \\
\hline Basal Diet (BD) & 89.61 & 93.41 & 19.52 & 3.25 & 3.39 & 67.25 & 6.59 & 3.43 & 0.46 \\
\hline $\begin{array}{l}\text { BD+ NSP enzyme } \\
\text { BD+ Synbiotics }\end{array}$ & 92.05 & 93.80 & 19.62 & 3.24 & 3.38 & 67.56 & 6.20 & 3.44 & 0.46 \\
\hline +Phytase & 89.78 & 93.39 & 19.41 & 3.32 & 3.35 & 67.31 & 6.61 & 3.36 & 0.45 \\
\hline $\begin{array}{l}\text { BD+NSP enzyme + } \\
\text { Synbiotics +Phytase }\end{array}$ & 90.58 & 93.49 & 19.46 & 3.35 & 3.38 & 67.24 & 6.57 & 3.34 & 0.46 \\
\hline
\end{tabular}

DM: Dry matter, OM: Organic matter, CP: Crude protein, EE: Ether extract, CF: Crude fiber, NFE: Nitrogen free extract, GE: Gross energy, TP: Total phosphorus. Each value is average of duplicate analysis

Table-5. Effect of feeding low calorie diet supplemented with NSP enzymes, synbiotics and phytase on performance and cost economics of broiler chicken

\begin{tabular}{|c|c|c|c|c|c|c|c|c|}
\hline \multirow[t]{2}{*}{ Diet } & \multicolumn{2}{|c|}{ Body weight (g) } & \multicolumn{2}{|c|}{ Feed intake (g) } & \multicolumn{2}{|c|}{ Feed conversion ration } & \multicolumn{2}{|c|}{$\begin{array}{l}\text { Feed cost per kg } \\
\text { live weight gain (Rs) }\end{array}$} \\
\hline & 0-3 wks. & 0-6 wks. & $0-3$ wks. & 0-6 wks. & 0-3 wks. & 0-6 wks. & 0-3 wks & 0-6 wks. \\
\hline Standard diet (SD) & 463.2 & 1494 & $726.0^{c}$ & $3013^{a}$ & $1.57^{\mathrm{b}}$ & $2.02^{\mathrm{ab}}$ & $31.55^{b}$ & $40.50^{\mathrm{a}}$ \\
\hline Basal Diet (BD) & 448.8 & 1436 & $789.7^{\mathrm{a}}$ & $2953^{\mathrm{ab}}$ & $1.77^{\mathrm{a}}$ & $2.06^{\mathrm{a}}$ & $34.08^{a}$ & $39.57^{\mathrm{ab}}$ \\
\hline BD+ NSP enzyme & 471.3 & 1495 & $774.5^{\mathrm{ab}}$ & $2895^{\mathrm{b}}$ & $1.64^{b}$ & $1.94^{\mathrm{abc}}$ & $31.74^{\mathrm{b}}$ & $37.22^{\mathrm{bc}}$ \\
\hline BD + Synbiotics+ Phytase & 479.6 & 1511 & $768.5^{\mathrm{b}}$ & $2886^{\mathrm{b}}$ & $1.61^{\mathrm{b}}$ & $1.91^{\mathrm{bc}}$ & $31.77^{\mathrm{b}}$ & $37.49^{\text {bc }}$ \\
\hline $\begin{array}{l}\text { BD + NSP enzymes+ } \\
\text { Synbiotics + Phytase }\end{array}$ & 486.4 & 1543 & $764.8^{b}$ & $2874^{b}$ & $1.57^{b}$ & $1.86^{c}$ & $35.92^{a}$ & $36.57^{c}$ \\
\hline SEM & 4.67 & 13.94 & 4.82 & 16.14 & 0.02 & 0.02 & 0.41 & 0.44 \\
\hline$P$ value & 0.084 & 0.179 & 0.001 & 0.017 & 0.001 & 0.016 & 0.001 & 0.009 \\
\hline
\end{tabular}

a-c: Means with different superscripts in a column differ significantly $(\mathrm{P}<0.05)$

residue and feces pooled during 4 days period were ground and analyzed for proximate principles as per method described previously [6]. After metabolic trial, 30 birds comprising of 6 birds from each diet by selecting one at random from each replicate) were slaughtered to assess the carcass characteristics.

Gut health: To study the effect of dietary energy concentration, supplementary effect of NSP enzymes, synbiotics and phytase on gut health, the digesta was collected from distal portion of small intestine during slaughter. Approximately two grams of digesta was taken in sterile eppendorf tubes for enumeration of $E$. coli. Another $2 \mathrm{~g}$ of digesta was collected and centrifuged at $5000 \mathrm{rpm}$ for 10 minutes at $20^{\circ} \mathrm{C}$. An aliquot of supernatant ( 0.5 to $1 \mathrm{ml}$ ) was collected and stored in capped vials for viscosity determination. The digesta collected in centrifuge tubes was utilized for measuring the $\mathrm{pH}$.

Histology of intestines: Representative pieces of duodenum of intestine were collected in $10 \%$ formal saline and preserved for histological studies. After proper fixation the intestinal tissue was trimmed and subjected to over night washing, dehydration in various percentages of alcohol, cleaning in xylol, embedding in paraffin wax for preparation of blocks [7]. The paraffin blocks were cut into $5 \mu$ thick sections and stained with routine $\mathrm{H} \&$ E stain [8] and used for microscopic examination.

Statistical analysis: The data were subjected to statistical analysis using Statistical Package for Social Sciences (SPSS) $16^{\text {th }}$ version and comparison of means was tested using Duncan's multiple range tests [9].

\section{Results}

Nutrient composition of experimental ration: Nutrient composition (\% dry matter basis) of broiler finisher standard and basal diets is presented in Table-4.

Body weight gain (g): The body weight gain in broiler chicks fed with BD supplemented with NSP enzymes, synbiotics and phytase is presented in Table-5. Significantly higher $(\mathrm{P}<0.01)$ weight gains were observed during $1^{\text {st }}$ week in broiler chicks fed with basal diet (BD) supplemented with synbiotics and phytase $(80.83 \mathrm{~g})$ or BD supplemented with NSP enzymes, synbiotics and phytase $(81.47 \mathrm{~g})$ compared to BD (63.50g) and SD (68.57g). Starter phase, finisher phase and total period (1- $42 \mathrm{~d}$ ) no difference in weight gain was observed among the chicks fed with SD, BD, BD supplemented with NSP enzymes, BD supplemented with synbiotics and phytase or in combination of synbiotics, phytase and NSPenzymes.

Feed intake (g/ bird/ day): The feed intake by chicks fed SD during starter phase was higher $(\mathrm{P}<0.01)$ than BD, BD supplemented with NSP enzymes, BD supplemented with synbiotics and phytase or BD in combination of all feed additives fed chicks (Table-5). Supplementation of NSP enzymes, synbiotics and phytase alone or in combination had significant effect on feed intake. Supplementation of NSP enzymes or synbiotics and phytase alone or in combination of all above feed additives to $\mathrm{BD}$ reduced $(\mathrm{P}<0.01)$ the feed intake. The starter phase feed intake was higher $(\mathrm{P}<0.01)$ in BD fed chicks than SD and comparable to BD supplemented with NSP enzymes. The addition of NSP enzymes, synbiotics and phytase to BD reduced $(\mathrm{P}<0.001)$ the feed intake in chicks but was higher than those fed SD. During finisher phase the feed intake by $\mathrm{BD}$ fed chicks was lower $(\mathrm{P}<0.001)$ than SD fed chicks and addition of feed additives alone or in combination had no effect on feed intake. While overall feed intake was higher $(\mathrm{P}<0.001)$ in SD but comparable to BD and 
Table-6. Nutrient retention, intestinal pH, viscosity, E. coli and tibia ash content of broilers fed basal diet supplemented with NSP enzymes, synbiotics and phytase

\begin{tabular}{|c|c|c|c|c|c|c|c|c|c|c|c|c|}
\hline \multirow[t]{2}{*}{ Diet } & \multicolumn{8}{|c|}{ Nutrient retention (\%) } & \multicolumn{3}{|c|}{ Gut condition } & \multirow{2}{*}{ Tibia ash(\%) } \\
\hline & DM & OM & $\mathbf{C P}$ & CF & EE & NFE & GE & $\mathbf{P}$ & $\mathrm{pH}$ & $\mathrm{V}(\%)$ & $\begin{array}{l}\text { E. coli } \\
\text { (cfu/ml) }\end{array}$ & \\
\hline Standard diet (SD) & 66.12 & $73.30^{\mathrm{a}}$ & $62.69^{\mathrm{a}}$ & 32.10 & 76.81 & $75.46^{\mathrm{b}}$ & $66.74^{\text {cd }}$ & $31.14^{c}$ & 6.17 & $8.12^{\mathrm{a}}$ & $4.34^{b}$ & $46.39^{\mathrm{a}}$ \\
\hline Basal diet (BD) & 67.20 & $68.87^{\mathrm{b}}$ & $54.75^{\mathrm{b}}$ & 29.06 & 71.29 & $77.08^{\mathrm{ab}}$ & $63.81^{d}$ & $31.59^{c}$ & 6.16 & $7.01^{\mathrm{b}}$ & $6.68^{a}$ & $42.74^{\mathrm{b}}$ \\
\hline BD + NSP enzymes & 69.89 & $72.12^{\mathrm{a}}$ & $60.72^{\mathrm{a}}$ & 32.18 & 74.56 & $79.51^{\mathrm{ab}}$ & $70.28^{\mathrm{bc}}$ & $32.70^{\mathrm{bc}}$ & 5.60 & $4.25^{c}$ & $5.28^{b}$ & $46.39^{\mathrm{a}}$ \\
\hline $\begin{array}{l}\text { BD + synbiotics } \\
\text { +phytase }\end{array}$ & 68.57 & $72.22^{\mathrm{a}}$ & $61.89^{\mathrm{a}}$ & 32.15 & 74.56 & $82.12^{\mathrm{a}}$ & $72.27^{\mathrm{ab}}$ & $35.21^{\mathrm{ab}}$ & 5.92 & $4.71^{c}$ & $1.32^{c}$ & $47.74^{\mathrm{a}}$ \\
\hline $\begin{array}{l}\text { BD + NSP enzymes } \\
+ \text { synbiotics + phytase }\end{array}$ & 71.57 & $73.45^{\mathrm{a}}$ & $63.80^{\mathrm{a}}$ & 31.36 & 76.07 & $81.73^{\mathrm{a}}$ & $76.65^{\mathrm{a}}$ & $36.19^{\mathrm{a}}$ & 5.74 & $3.81^{c}$ & $1.97^{\mathrm{c}}$ & $47.89^{\mathrm{a}}$ \\
\hline SEM & 0.81 & 0.55 & 1.03 & 0.68 & 0.75 & 0.89 & 1.21 & 0.63 & 0.08 & 0.41 & 0.49 & 0.57 \\
\hline$P$ value & 0.222 & 0.038 & 0.026 & 0.586 & 0.165 & 0.056 & 0.001 & 0.017 & 0.074 & 0.001 & 0.001 & 0.007 \\
\hline
\end{tabular}

P: Phosphorus, V: Viscosity, a-c: Means with different superscripts in a column differ significantly $(P<0.05)$

Table-7. Effect on slaughter characteristics of broilers fed low calorie diet supplemented with NSP enzymes, synbiotics and phytase

\begin{tabular}{|c|c|c|c|c|c|c|}
\hline \multirow[t]{2}{*}{ Diet } & \multirow[t]{2}{*}{ Dressing yield (\%) } & \multirow[t]{2}{*}{ B reast yield (\%) } & \multirow[t]{2}{*}{ Abdominal fat (\%) } & \multicolumn{3}{|c|}{ Visceral organs (\% of body weight) } \\
\hline & & & & Liver & Heart & Gizzard \\
\hline Standard diet (SD) & 63.67 & 18.89 & 1.04 & 2.18 & $0.60^{\mathrm{b}}$ & 2.66 \\
\hline Basal diet(BD) & 64.61 & 19.62 & 0.89 & 2.10 & $0.69^{\mathrm{a}}$ & 2.55 \\
\hline BD + NSP enzymes & 64.78 & 18.39 & 1.07 & 2.25 & $0.62^{a b}$ & 2.47 \\
\hline BD + Synbiotics + Phytase & 64.57 & 19.05 & 0.64 & 2.09 & $0.67^{\mathrm{a}}$ & 2.29 \\
\hline $\begin{array}{l}\text { BD + NSP enzymes + } \\
\text { Synbiotics + Phytase }\end{array}$ & 66.67 & 19.44 & 0.79 & 2.07 & $0.68^{a}$ & 2.59 \\
\hline SEM & 0.35 & 0.18 & 0.06 & 0.04 & 0.01 & 0.05 \\
\hline$P$ value & 0.066 & 0.236 & 0.156 & 0.710 & 0.046 & 0.135 \\
\hline
\end{tabular}

Means with different superscripts in a column differ significantly $(P<0.05)$

addition of synbiotics, phytase and NSP enzymes reduced the feed intake compared to SD.

Feed conversion ratio: Supplementation of NSP enzymes or synbiotics with phytase or combination of all feed additives improved $(\mathrm{P}<0.01)$ the $\mathrm{FCR}$ compared to SD and BD (Table-5). Supplementation of synbiotics and phytase or NSP enzymes alongwith synbiotics and phytase to BD improved the FCR $(\mathrm{P}<0.01)$ in comparison to $\mathrm{BD}$ and $\mathrm{SD}$. No significant effect of supplementing NSP enzymes, synbiotics and phytase was observed on FCR during finisher phase. The FCR of BD fed chicks during starter phase was higher $(\mathrm{P}<0.001)$ than those fed SD. Supplementing $\mathrm{BD}$ with NSP enzymes or synbiotics and phytase or combination of all feed additives improved the FCR in starter phase and comparable to SD. During finisher phase and overall period, the FCR was comparable between SD and BD. Synergistic effect of NSP enzymes, synbiotics and phytase was observed for FCR during finisher phase (1.99) and overall period (1.86) which improved $(\mathrm{P}<0.05)$ compared to $\mathrm{BD}$ (2.20) and SD (2.06).

Nutrient retention: The supplementation of NSP enzymes, synbiotics and phytase to BD improved $(\mathrm{P}<0.05)$ utilization of OM, CP, NFE, GE and phosphorus compared to BD (Table-6). The OM retention was higher $(\mathrm{P}<0.05)$ for $\mathrm{BD}$ supplemented with NSP enzymes, synbiotics and phytase $(73.45 \%)$ followed by SD (73.30\%) and lowest DM retention was observed in BD $(68.87 \%)$. Similar to OM the retention of $\mathrm{CP}$ was highest $(\mathrm{P}<0.05)$ for $\mathrm{BD}$ supplemented with NSP enzymes, synbiotics and phytase $(63.80 \%)$ than BD $(54.75 \%)$. Supplementing synbiotics and phytase to BD increased $\mathrm{CP}$ retention and it reached to the level of SD. The retention of NFE improved $(\mathrm{P}<0.05)$ with addition of synbiotics, phytase and NSP enzymes to BD and the NFE retention was comparable to SD and BD with NSP enzymes. The GE retention was higher $(\mathrm{P}<0.01)$ for $\mathrm{BD}$ supplemented with NSP enzymes, synbiotics and phytase $(76.65 \%)$ followed by BD supplemented with synbiotics and phytase $(72.27 \%)$ and lowest GE retention was observed in BD (63.81\%). Addition of NSP enzymes in combination with synbiotics and phytase improved $(\mathrm{P}<0.005)$ phosphorus retention significantly compared to SD (31.14\%), BD (31.59\%), BD supplemented with NSP enzymes (32.70\%). However the phosphorus retention was comparable between synbiotics group and BD supplemented with NSP enzymes, synbiotics and phytase. The tibia ash content was lower in BD (42.74\%) compared to SD (46.39). Supplementing BD with NSP enzymes or with synbiotics and phytase or combination of synbiotics, phytase and NSP enzymes improved the tibia ash content and was comparable to SD (Table-6).

Carcass characteristics: The slaughter attributes in terms of dressing yield, breast yield, abdominal fat and visceral organs viz., liver, heart and gizzard is presented in Table-7.

No significant $(\mathrm{P}<0.05)$ effect was observed among broilers fed SD, BD, BD supplemented with NSP enzymes, synbiotics and phytase alone or in combination on dressing yield, breast yield, and abdominal fat and it varied from 63.67 to $66.67 \% 18.39$ to $19.44 \%$ and 0.64 to $1.07 \%$, respectively. Similarly no significant effect $(\mathrm{P}<0.05)$ of supplementation of BD with NSPenzymes, combination of synbiotics and phytase or combination of synbiotics, phytase and NSP 
enzymes was observed on liver, gizzard weights (Table-7) and the values ranged from 2.07 to $2.25 \%$ and 2.29 to $2.66 \%$, respectively.

Gut conditions: No significant $(\mathrm{P}<0.05)$ effect of supplementation of various feed additives to BD was observed on intestinal $\mathrm{pH}$ and the values varied between 5.60 and 6.17 . The intestinal viscosity varied from 3.81 to $8.12 \%$. The supplementation of BD with NSP enzymes $(4.25 \%)$ or synbiotics and phytase $(4.71$ $\%)$ or combination of all feed additives $(3.81 \%)$ reduced $(\mathrm{P}<0.01)$ the intestinal viscosity compared to SD $(8.12 \%)$ and BD $(7.01 \%)$ (Table-6). The intestinal viscosity was higher in SD compared to BD. The E. coli count $\left(\log _{10}\right)$ in intestinal contents was lowest $(\mathrm{P}<0.001)$ in SD (4.34) compared to BD (6.68) (Table 6). Supplementation of synbiotics with phytase (1.32) or combination of all feed additives (1.97) lowered the E. coli count in intestinal contents in comparison to BD and SD.

Gut histology: The supplementation of NSP enzymes along with synbiotics and phytase did not influence the intestinal histology, except few broad elongated and folded, congested villi with presence of few goblet cells was noted (Figure-1).

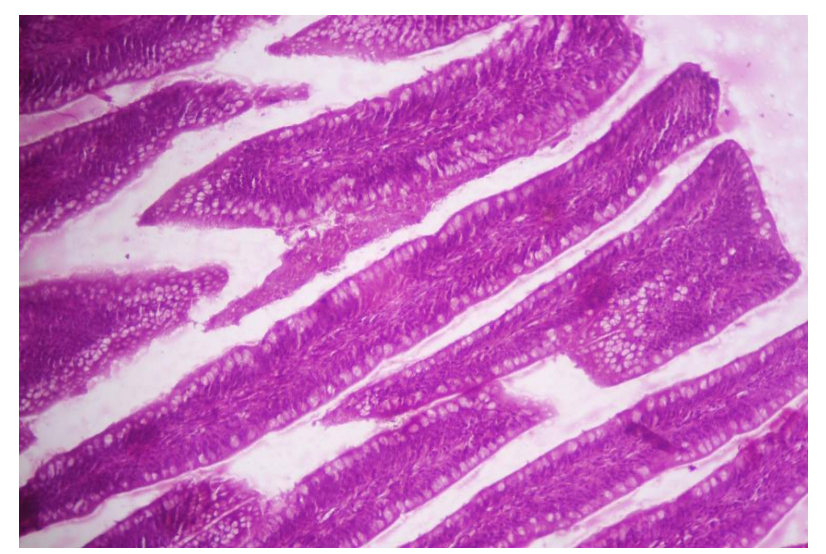

Figure-1. H\&E section of duodenum showing broad villi at tip with distinct goblet cell activity

Cost comparison: The cost of production per kg live weight gain during starter and finisher phases of broiler production is given in Table-5. The cost of production per kg live weight gain during starter phase was higher $(\mathrm{P}<0.01)$ for BD (Rs. 34.08) compared to SD (Rs. 31.55). Supplementing BD with NSP enzymes (Rs. 31.74) or synbiotics alongwith phytase (Rs. 31.77) reduced the cost of production per $\mathrm{kg}$ weight gain compared to BD, but was similar to SD. Addition of all the feed additives to BD increased the feed cost (Rs. 35.92) compared to all other groups during starter phase. During finisher phase, cost of production was highest $(\mathrm{P}<0.01)$ for SD (Rs. 40.50) but comparable with BD (Rs. 39.57). Supplementation of NSP enzymes, synbiotics along with phytase or all feed additives reduced $(\mathrm{P}<0.01)$ the cost of production compared to SD during finisher phase. Similarly the overall cost of production was similar between SD and BD. Feeding of BD containing either NSP enzymes
(Rs. 37.22) or synbiotics with phytase (Rs. 37.49) reduced the cost of feed to SD (Rs. 40.50), but comparable to that of BD (Rs. 39.57). Supplementing all the above feed additives to BD significantly $(\mathrm{P}<0.01)$ reduced the cost of production (Rs. 36.57) compared to BD and SD.

\section{Discussion}

Body weight gain: Effect of supplementing different feed additives, NSP enzymes, synbiotics and phytase to $\mathrm{BD}$ individually or combination of all had significantly $(\mathrm{P}<0.005)$ improved body weight gain during $1^{\text {st }}$ week of experiment (Table-5). The starter, finisher and total weight gains recorded was though comparable among various groups, higher weight gain of $7.48 \%$ was recorded with supplementation of all feed additives to BD. The results are in agreement with $[10,11]$ who reported improvement in weight gains with supplementation of various feed additives (avilamycin, allzyme, avimos, biomos, yeast extract, xylanase, avizyme and gustor) individually or in combination. Improvement in live weight gain was also reported [12] when broiler diets supplemented with direct fed microbials (DFM), antibiotic growth promoters (AGP) and Biomos compared to control. However, contrary to present findings, addition of prebiotics (galacto oligosacharides) and probiotics (Bifiodobacteriam lactic $300 \times 10^{9}$ cells $/ \mathrm{g}$ ) individually or in combination had no effect on body weight gain [13].

Feed intake: During starter period feed intake $(\mathrm{g} / \mathrm{d})$ was higher $(\mathrm{P}<0.05)$ in $\mathrm{BD}$ compared to $\mathrm{SD}$ and $\mathrm{BD}$ supplemented with feed additives (Table-5). However, significantly higher $(\mathrm{P}<0.01)$ feed intake was recorded in $\mathrm{SD}$ fed birds during finisher period compared to $\mathrm{BD}$ and BD supplemented with various feed additives. Feed intake was lowest in BD supplemented with various feed additives.

The results are in line with a previous report [10] who studied that effect of various feed additives (Avilamycin, Allzyme, Avimos, Biomos, Yeast extract, xylanase, Avizyme and Gustor) individually and combination had no effect on DM intake over the entire 1-28 day experimental period. Mean feed intake for the whole period was numerically greatest for the birds fed on positive control. The average daily feed intake (ADFI) of birds fed with direct fed microbials (DFM), antibiotic growth promoters (AGP) and Biomos was insignificant compared to control [12]. It was found no effect of feed additives (xylanase, protease and phytase) when supplemented to nutritionally marginal ( $2870 \mathrm{kcal}$ of $\mathrm{ME} / \mathrm{kg}, 0.85 \% \mathrm{Ca}$ and $0.24 \%$ available $\mathrm{P}$ ) corn soy bean based diets on feed intake [14]. However, a study [11] reported that diets supplemented with performance enhancers (prebiotics, probiotics and organic acids either alone or in combination) had significantly influenced feed intake for 21 day $(\mathrm{P}<0.05)$ period but not at 0 to 42 day period.

Feed conversion ratio: Birds fed with $\mathrm{BD}$ had poorer 
$(\mathrm{P}<0.05)$ feed conversion efficiency compared with those fed with SD. Supplementation of NSP enzymes, synbiotics and phytase and combination of all improved feed conversion efficiency linearly indicating synergistic effect of addition of two or more feed additives to low calorie diets (Table-5). Earlier it was reported that significant improvement in FCR with addition of various feed additives (avilamycin, allzyme, avimos, biomass, yeast extract, avizyme and gustor), combination of prebiotics and probiotics compared to control and xylanase, protease, amylase and phytase to nutritionally marginal $(2870 \mathrm{kcal}$ of $\mathrm{ME} / \mathrm{kg}, 0.85 \% \mathrm{Ca}$ and $0.24 \%$ available $\mathrm{P}$ ) corn soy bean based diets $[10,11,14]$. However another study [15] observed that addition of xylanase, amylase, protease and phytase alone to low density diets had no effect on feed conversion ratio, but combination had significantly $(\mathrm{P}<0.05)$ improved feed efficiency compared to the negative control.

Nutrient retention: The supplementation of NSP enzymes, synbiotics and phytase alone or in combination of all improved the retention of $\mathrm{OM}, \mathrm{CP}$, NFE, GE and phosphorus (Table 6). Whereas DM, CF and $\mathrm{EE}$ retentions were not influenced by dietary treatments compared to $\mathrm{BD}$ and $\mathrm{SD}$. $\mathrm{BD}$ with synbiotics and phytase influenced the retention of $\mathrm{OM}$, $\mathrm{CP}, \mathrm{CF}$ and NFE. On the whole, the addition of NSP enzymes, synbiotics and phytase to $\mathrm{BD}$ improved $(\mathrm{P}<0.05)$ retention of these nutrients significantly. The results are in agreement with earlier report on improvement in AME and phosphorous retention by supplementation of phytase alone or in combination with NSP degrading enzymes and citric acid [16].

Supplementation of exogenous enzymes to the broiler diet improved starch digestibility and consequently DM, OM, CP and energy digestibilities. Improvement in ileal apparent digestibility coefficient (ADC) of CP and EE was reported [17] with addition of avilamycin $(2.5 \mathrm{~g} / \mathrm{kg}$ of diet $)$ and further improvement was observed when fortified with probiotics $\left(10^{8} \mathrm{CFU} / \mathrm{kg}\right)$ on total tract $\mathrm{ADC}$ for DM, ash, EE and ME values. The apparent digestibility of $\mathrm{DM}, \mathrm{OM}, \mathrm{CP}, \mathrm{EE}$, starch and energy were increased $(\mathrm{P}<0.05)$ with supplementation of enzymes [18]. However, a previous study [15] observed no improvement in apparent total tract retention of DM and energy as phytase or xylanase, amylase, protease could influence the retention including phosphorus.

Tibia ash content was significantly $(\mathrm{P}<0.001)$ higher in supplemented groups and SD compared to $\mathrm{BD}$ (Table 6). This might be due to synergistic effect of feed additives. The results are in agreement with [19] who reported the benefits of NSP enzymes and phytase supplementation to broiler diets which improved bone mineralization and reached to the level of positive control diet.

Carcass characteristics: The birds receiving different feed additives, either singly or in combination recorded in significantly $(\mathrm{P}>0.05)$ higher dressing per cent and breast yield per cent than SD and BD (Table 7). Similarly, dietary treatments had no effect on abdominal fat pad weight, liver and gizzard.

There was no effect of biomas, protexin and acidifier individually or combination of all on edible carcass yield, liver weight and gizzard weight [20]. However, on the other hand another study [21] reported improved dressing yield per cent $(\mathrm{P}<0.05)$ and breast yield per cent and other meat yield traits when supplemented with or without growth promoters (flavomycin, avilamycin, genex and avila $\mathrm{m} / \mathrm{z}$ ) and were comparable $(\mathrm{P}>0.05)$ among the groups.

Gut conditions: Supplementation of NSP enzymes, synbiotics and phytase alone and combination had no effect on intestinal $\mathrm{pH}$ values recorded among the treatment groups (Table-6). Whereas viscosity and $E$. coli count significantly $(\mathrm{P}<0.01)$ reduced in feed additives supplemented groups compared to $\mathrm{SD}$ and BD. The intestinal $\mathrm{pH}$ recorded were in agreement with earlier findings [20] that observed supplementing prebiotics, probiotics and acidifier singly or in combination had no effect on $\mathrm{pH}$. Viscosity recorded was in agreement with the earlier report [22] which indicated that the exogenous enzyme supplementation significantly $(\mathrm{P}<0.05)$ reduced the digesta viscosity. Previously significant effect on lactobacilli and coliform counts in ileum of the diets supplemented with different feed additives alone or in combination were reported [10].

Gut histology: The supplementation of NSP enzymes with synbiotics and phytase to BD resulted in broad villi at tip with distinct goblet cell activity (Figure 1). The effect of synbiotics (BIOMIN IMBO) increased (P $<0.001)$ villus height/crypt depth ratio and villus height in ileum [23].

Cost comparison: Feed cost per kg live weight gain was significantly $(\mathrm{P}<0.01)$ reduced by Rs. 3.93 and Rs. 3.00 in all feed additive group compared to SD and BD, respectively (Table-5). Similarly, reduced cost of production was observed in earlier studies [21] with supplementation of different growth promoters such (flavomycin, avilamycin, genex and avila $\mathrm{m} / \mathrm{z}$ ) in broiler diets. Feeding low calorie diet fortified with feed additives like NSP enzymes, synbiotics and phytase resulted in low cost of production and better returns.

\section{Conclusion}

From this study, it can be concluded that supplementing NSP enzyme, synbiotics and phytase in combination has exerted synergistic effect on body weight gain feed conversion efficiency, improvement in nutrient retentions and gut health at reduced cost of production in broilers fed corn-soybean meal based low energy diets.

\section{Authors' contributions}

JN and DN designed the experiment, implemented the 
design, analyzed data and prepared the manuscript; YRR and STVR revised manuscript. All authors read and approved the final manuscript.

\section{Acknowledgements}

The authors are pleased to thank Sri Venkateswara Veterinary University for providing fund and infrastructure during the study.

\section{Competing interests}

The authors declare that they have no competing interests.

\section{References}

1. Grashorn, M.A. (2010) Use of phytobiotics in broiler nutrition - an alternative to in feed antibiotics? Journal of Animal and Feed Sciences 19:338-347.

2. Panda, K., Rama Rao, S.V. and Raju, M.V.L.N. (2006) Natural growth promoters have potential in poultry feeding systems. Feed Technology 10 (8): 23-25.

3. Maiorka, A., Santin, A. M. E., Borges, S. A., Opalinski, M. and Silva, A. V. F. (2004) Evaluation of a mix of fumaric, lactic, citric and ascorbic acids on starter diets of broilers. Archives of Veterinary Science 9: 31-37.

4. Lokhande, D. Y., Ranade, A. S., Desai, D. N., Patil, M. B., Avari, P. E., Patwardhan, D. S., Adsul A. P. and Gaikwad, P. G. (2005) Comparative evaluation of prebiotic, probiotic and acidifier in broiler diets. Journal of Bombay Veterinary College 13 (1-2): 17-19.

5. National Research Council. (1994) Nutrient Requirements of Poultry. 9th ed. National Academy Press, Washington, DC.

6. AOAC. (2005) Official Methods of Analysis of Association of official Analytical chemists $18^{\text {th }}$ Edition (Virginia, USA, Association of official Analytical chemists).

7. Clayden, E. C. (1962) Practical section cutting and staining. $4^{\text {th }}$ Edition, J and Churchil limited. pages: 137-139.

8. Culling, C. F. A. (1957) Hand Book of Histopathological Techniques. London Butterworth and company (publisher) Ltd. pages: 421-427

9. Duncan, D. D. (1955) Multiple range and multiple ' F' test, Biometrics 11:1-42.

10. Owens, B., Tucker, L., Collins, M. A. and Mc Cracken K. J. (2008) Effects of different feed additives alone or in combination on broiler performance, gut microflora and ileal histology. British Poultry Science 49 (2): 202-212.

11. Bozkurt, M. K., Kucukylmaz, A., Çatl, U. and Çnar, M. (2009) The effect of single or combined dietary supplementation of prebiotics, organic acid and probiotics on performance and slaughter characteristics of broilers. South African Journal of Animal Science 39 (3): 45 - 52.

12. Markovic, R., Sefera, D., Krstic, M. and Petrujkic, B. (2009) Effect of different growth promoters on broiler performance and gut morphology. Archives of Veterinary Medicine 41:
163-169.

13. Jung, S. J., Houde, R., Baurhoo, B., Zhao, X, and Lee, B. H. (2008) Effects of galacto-oligosaccharides and a Bifidobacteria lactis-based probiotic strain on the growth performance and faecal microflora of broiler chickens. Poultry Science 87: 1694-1699.

14. Cowieson, A. J. and Adeola, O. (2005) Carbohydrases, protease and phytase have an additive beneficial effect in nutritionally marginal diets for broiler chicks. Poultry Science 84: 1860-1867.

15. Olukosi, O. A., Cowieson, A. J. and Adeola, O. (2007) Agerelated influence of a cocktail of xylanase, amylase and protease or phytase individually or in combination in broiles. Poultry Science 86: 77-86.

16. Woyengo, T. A., Slominski, B. A. and Jones, R. O. (2010) Growth performance and nutrient utilization of broiler chickens fed diets supplemented with phytase alone or in combination with citric acid and multi carbohydrase. Poultry Science 89: 2221-2229.

17. Mountzouris, K. C., Tsitrsikos, P., Palamidi, I., Arvaniti, A., Mohnl, M., Schatzmayr, G. and Fegeros, K. (2010) Effects of probiotic inclusion levels in broiler nutrition on growth performance, nutrient digestibility, plasma immunoglobulins and cecal microflora composition. Poultry Science 89: 58-67.

18. Khan, S. H., Sardar, R. and Siddique, B. (2006) Influence of enzymes on performance of broilers fed sunflower-corn based diets. Pakistan Veterinary Journal 26 (3): 109-114.

19. Francesch, M. and Geraert, P. A. (2009) Enzyme complex containing carbohydrases and phytase improves growth performance and bone mineralization of broilers fed reduced nutrient corn-soybean based diets. Poultry Science 88: 19151924.

20. Munj, C. P., Ranade, A. S., Desai, D. N., Avari. P. E., Patil, U. M. and Metakari, D. V. (2010) Studies on synergistic effects of certain common feed additives on carcass quality, intestinal $\mathrm{pH}$ and gut microflora in broilers. Indian Journal Animal Nutrition 27 (1): 93-95.

21. Farran, M.T., Barbour, G.W., Usayron, N. N., Darwish, A.H., Hasan H. Matchhlals, H. H., Hruby, M. and Askarian, V. M. (2010) Performance and carcass quality of broiler chickens fed a corn-soybean meal diet containing graded barley levels without or with enzymes. Journal of Poultry Science 47: 34-40.

22. Nadeem, M. A., Anjum, M. I., Khan, A. G. and Azim, A. (2005) Effect of dietary supplementation of non-starch polysaccharide degrading enzymes on growth performance of broiler chicks. Pakistan Veterinary Journal 25 (4): 183188.

23. Wageha, A., Ghareeb, K. and Bohm, J. (2008) Intestinal structure and function of broiler chickens on diets supplemented with a symbiotic containing Enterococcus faecium and oligosaccharides. International Journal of Molecular Science 9(11): 2205-2216. 